\title{
Contents, Vol. 1, 1957
}

\section{Gerontologia}

Zeitschrift für experimentell-biologische und-medizinische Alternsforschung -Journal of Experimental Biological and Experimental Medical Research on Ageing - Journal de Recherches expérimentales, biologiques et médicales, sur le vieillissement

Editor: F. Verzár, Basel

R. E. Tunbridge

Leeds

Goed $\gamma \gamma$ ores :

F. Bourlière

Paris

C. M. McCay

Ithaca, N.Y.

COLLABORATORES:

A. v. Albertini, Zurich W. Andrew, Winston-Salem, N. C. J. Baló, Budapest J. Bang a, Budapest L. Binet, Paris J. E. Birren, Bethesda, Md. G. H. Bourne,

Emory University, Ga. E. Braun-Menendez,

Buenos Aires L. Brull, Liège J. Danielli, London

W. DOBERAUER, WIEN

G. Di Macco, Roma K. J. Franklin, London

T. Geill, København

T. Gillman, Durban

E. Greppi, Firenze

J. Groen, Amsterdam

L. Haranghy, Budapest

E. Jalavisto, Helsinki

W. J. E. Jessup, Dublin

V. R. Khanolkar, Bombay

P. S. Krishnan, Lucknow

K. Miescher, Basel

O. Mühlbock, Amsterdam

R. Nicolaysen, Oslo

J. H. Sheldon, Wolverhampton

A. L. Vischer, Basel

R. Wagner, München

1957

Vol. 1, No. 6

BASEL (Schweiz) S. KARGER NEW YORK 
Alle Rechte, insbesondere das der Übersetzung in fremde Sprachen, vorbehalten.

Ohne ausdrückliche Genehmigung des Verlages ist es auch nicht gestattet, díesen Band oder Teile daraus

auf photomechanischem Wege (Photokopie, Mikrokopie) zu vervielfältigen.

(c)

Copyright 1957 by S. Karger AG, Basel

Printed in Switzerland by Buchdruckerei National-Zeitung AG, Basel

Cliches: Aberegg-Steiner \& Cie. AG, Bern

Index

ORIGINAL PAPERS - ORIGINALARBEITEN - TRAVAUX ORIGINAUX

Baló, J., Banga, I.,

JUHÁSZ, J., SZABÓ, D.

and Szalay, E. Banga, I.

Banga, I. Bentor, V.

BONDAREFF, W.

BOURLIÈRE, F. BOURLIÈRE, F.,

Joseph, N. R. and Molimard, R.

Bourne, G. H. Clay, H. M.

Fabry, P.

Freydberg-Lucas, V. and Verzâr, F.

Friedman, C. L.

Friedman, S. M. and Friedman, C. L.

Friedman, S. M. and Friedman, C. L.

Gerking, S. D.

Greppi, E.

Hall, D. A.

Hruza, Z. and Fabry, P.

Hügin, F. and Verázr, F.

Joseph, N. R.

Joseph, N. R.,

Molimard, R. and Bourlière, F.

Juhâsz, J.

Effect of Intraperitoneal Administration of Elastase

on White Rats 315

Der Effekt der schwachen organischen Säuren auf

die Rattenschwanz-Kollagenfasern yon jungen und

altenTieren 325

vide Balô, J.

vide Wertheimer, E.

Sabmicroscopic Morphology of Connective Tissue

Ground Substance with Particular Regard to Fi-

brillogenesis and Aging

222

vide Joseph, N. R.

Ageing of Skin. 2. Adaptive Responses in Rat Der-

mis in Relation to Age and Growth 163 
Changes in Dephosphorylating Enzymes in Young and Old Tissues of the Rat 50

The Relationship between Time, Accuracy and Age on Similar Tasks of Varying Complexity 41 vide Hruza, Z.

Der Calciumstoffwechsel verschiedener Organe bei jungen und alten Tieren 195 vide Friedman, S. M.

Salt and Water Balance in Ageing Rats 107

Salt and Water Balance in Relation to Blood Pres sure in Ageing Rats 127

Evidence of Aging in Natural Populations of Fishes 287

Effects of Large Ingestion of Butter and other Foods

on Haematic Features in Ageing 214

Collagen and Elastin: The Effect of Age on their

Relationship 347

Some Metabolic and Endocrine Changes due to Long

Lasting Caloric Undernutrition 279

Versagen der Wärmeregulation bei alten Tieren. . 91

vide Bourlière, $\mathrm{F}$.

Ageing of Skin. 1. Titration Curves of Human Epi

dermis in Relation to Age 18

vide Baló, J.

LINDOP, P. J. LüNSFORD, W.

McCay, C. M., Pope, F.,

LUNSFORD, W.,

Sperling, G. and Sambhavaphol, P.

MOLIMARD, R. MOLIMARD, R.

Pope, F.

Sambhavaphol, P. Saxl, H.

Sperling, G.

Szabô, D.

Szalay, E.

Thung, P. J.

Verzâr-McDougall, E. J

Verzár, F.

Verzár, F.

Verzår, F.

Wertheimer, E. and Bentor, V.

CRITICAL REVIEWS -Alexander, P.

Thung, P. J.

Verzár, F.

The Effect of Age on the Renal Response to a Stress 86 vide McCay, C. M.

Parabiosis between Old and Young Rats 7

vide Bourlière, $\mathrm{F}$.

vide Joseph, N. R. 
vide McCay, C. M.

vide McCay, C. M.

The Physiological Significance of the Reaction be tween Elastin and Elastomucase in Relation to the

Production of "Clearing Factor" 142

vide McCay, C. M.

vide Baló, J.

vide Baló, J.

Senile Amyloidosis in Mice 259

, Studies in Learning and Memory in Ageing Rats. . 65

Editorial/Zum Geleit/Avant-propos 1

vide Freydberg-Lucas, V.

vide Hügin, F.

Adaptation of Young and Old Rats to Short Cold

Exposure $\quad 306$

ÜBERSICHTSREFERATE - REVUES GÉNÉRALES

Accelerated Ageing - a Long Term Effect of Expo

sure to Ionizing Radiations 174

The Relation between Amyloid and Ageing in Com

parative Pathology 234

The Ageing of Connective Tissue 363

Conferences - Kongresse - Congrès

First Pan-American Congress of Gerontology ... 60 Symposium de Gatlinburg sur les processus biolo-

giques fondamentaux du vieillissement 254

IV th Congress of the International Association of

Gerontology 312

Obituaries - Nachrufe - Necrologies

Felix Bernstein 123

Oscar Olbrich 313

Book Reviews - Buchbesprechungen - Livres Nouveaux .... 59, 124, 258, 379

News Items - Nachrichten - Nouvelles $\quad 63,121,126,193,257$

Register rerum ad Vol. $1 \quad 380$ 